\title{
Tateyamaria pelophila sp. nov., a facultatively anaerobic alphaproteobacterium isolated from tidal- flat sediment, and emended descriptions of the genus Tateyamaria and of Tateyamaria omphalii
}

Correspondence
Henrik Sass
SassH@cardiff.ac.uk

During the last two decades, molecular methods have helped to vastly expand our knowledge of microbial diversity and to identify the dominant bacterial phyla in various environments. Most of these new phyla are not represented in culture collections as no isolates are available so far (Hugenholtz et al., 1998; Rappé \& Giovannoni, 2003). A notable exception is the Roseobacter clade within the class Alphaproteobacteria (Selje et al., 2004; Buchan et al., 2005). Bacteria in the Roseobacter clade are globally distributed and form one of the

Abbreviations: AODS, anthraquinone-2,6-disulfonic acid; DPG, diphosphatidylglycerol; MPN, most probable number; $\mathrm{PC}$, phosphatidylcholine; $P E$, phosphatidylethanolamine; $P G$, phosphatidylglycerol; TMAO, trimethylammonium oxide.

The GenBank/EMBL/DDBJ accession number for the 16S rRNA gene sequence of Tateyamaria pelophila SAM4 ${ }^{\top}$ is AJ968651.

Plots showing the effect of temperature on growth of strain SAM4 ${ }^{\top}$ (supplementary Fig. S1) are available with the online version of this paper. dominant groups of marine bacterioplankton (Mullins et al., 1995; Gonzalez \& Moran, 1997). Selje et al. (2004) found up to $2 \times 10^{5}$ Roseobacter clade cells $\mathrm{ml}^{-1}$ in North Sea water, corresponding to approximately $20 \%$ of the total DAPI cell count. Although Roseobacter clade bacteria are generally strict aerobes, they have also been detected repeatedly in marine sediments by molecular methods as well as by cultivation (Johnson \& Hill, 2003; Süß et al., 2004; Buchan et al., 2005; Köpke et al., 2005). Gonzalez et al. (1999) estimated that members of the Roseobacter clade may account for up to $11 \%$ of the $16 \mathrm{~S}$ rRNA gene copies in coastal sediment communities. Such a high abundance cannot be explained solely by the survival of strictly aerobic bacteria during burial or by oxic microlayers around the burrows of macrozoobenthos. During a quantitative cultivation study performed with tidal-flat sediments taken close to the village of Neuharlingersiel on the German North Sea coast in October 1998, strain $\mathrm{SAM} 4^{\mathrm{T}}$ was enriched and isolated from a most probable number (MPN) series prepared with sediments from $5 \mathrm{~cm}$ 
depth using oxic medium and with amino acids as electron donors ( $2 \mathrm{mM}$ alanine and $1 \mathrm{mM}$ each of cystine, arginine and asparagine). Strain $\mathrm{SAM} 4{ }^{\mathrm{T}}$ was identified as a member of the Roseobacter clade and, although isolated under oxic conditions, was able to grow anaerobically.

The closest relative of strain SAM4 $4^{\mathrm{T}}$, Tateyamaria omphalii IAM $15108^{\mathrm{T}}$, was purchased from the Japan Collection of Microorganisms. Microbiological routine tests (Gram and flagella-staining, oxidase, catalase, enzyme activities) were performed with exponential phase cells according to standard procedures (Gerhardt et al., 1994). Bacteriochlorophyll was determined spectrophotometrically (Cohen-Bazire et al., 1957) with cells grown on marine broth 2216 (MB; Difco, Becton Dickinson) in the dark or under diurnal light/dark cycles. Absorption spectra were recorded from $400-900 \mathrm{~nm}$ on a UV/VIS spectrophotometer (Lambda2S; Perkin Elmer). The G $+\mathrm{C}$ content of the DNA was determined by HPLC analysis (Mesbah et al., 1989) at the German Collection of Microorganisms and Cell Cultures (DSMZ, Braunschweig, Germany). For preparation of the MPN series, isolation and growth of pure cultures, a HEPES-buffered artificial oxic seawater medium was used (Süß et al., 2004; Köpke et al., 2005). For tests on anaerobic growth, the medium was cooled under an $\mathrm{N}_{2} / \mathrm{CO}_{2}(80: 20, \mathrm{v} / \mathrm{v})$ atmosphere and buffered by the addition of sodium bicarbonate $\left(30 \mathrm{mmol} \mathrm{l}^{-1}\right.$ final concentration) from sterile stocks (Süß et al., 2004). The anoxic basal medium contained resazurin $\left(0.25 \mathrm{mg} \mathrm{l}^{-1}\right)$ as a redox indicator and was reduced by the addition of a few crystals of sterile sodium dithionite or sodium sulfide until the redox indicator turned colourless. For strain maintenance and some growth tests, an oxic dilute yeast extractpeptone-glucose medium (YPG) based on the oxic seawater medium described above was used (Süß et al., 2004). Strain SAM4 $4^{\mathrm{T}}$ grew on $\mathrm{MB}$, but cells often appeared very pleomorphic and growth was not always reproducible. Substrate utilization was tested in miniaturized assays in microtitre plates (Corning) using oxic mineral medium. For each substrate, an inoculum-free control was prepared and for each strain, a substrate-free blank was prepared (Süß et al., 2008). Growth was checked by fluorimetry (Köpke et al., 2005; Martens-Habbena \& Sass, 2006) and by subculturing. Fermentative growth was tested in anoxic sulfate-free medium with either glucose $(5 \mathrm{mM})$ or Casamino acids $(0.1 \%)$, or in anoxic sulfide-reduced $\mathrm{MB}$ or R2A medium (Becton Dickinson). Tests for anaerobic respiration were performed with sulfate-free anoxic mineral medium with either sodium acetate or lactate (10 $\mathrm{mM}$ each) in combination with the following electron acceptors (Köpke et al., 2005; Süß et al., 2008): nitrate $(10 \mathrm{mM})$, nitrite $(2 \mathrm{mM})$, thiosulfate $(10 \mathrm{mM})$, sulfite $(5 \mathrm{mM})$, ferrihydrite $(20 \mathrm{mM})$, manganese oxides $(10 \mathrm{mM})$, elemental sulfur, trimethylammonium oxide (TMAO; $5 \mathrm{mM}$ ), DMSO (5 mM), anthraquinone-2,6-disulfonic acid (AQDS; $0.5 \mathrm{mM}$ ), or humic acids $\left(0.1 \mathrm{mg} \mathrm{ml}^{-1}\right.$; SigmaAldrich). Hydrogen consumption was tested in mineral medium under an $\mathrm{N}_{2} / \mathrm{CO}_{2}(80: 20, \mathrm{v} / \mathrm{v})$ gas phase containing
$5 \% \mathrm{O}_{2}$ and $10 \% \mathrm{H}_{2} . \mathrm{H}_{2}$ was analysed by GC (Webster et al., 2009). Manganese oxidation was tested in the dark in mineral medium containing $10 \mathrm{mM} \mathrm{MnCl} 2$. The $\mathrm{Na}^{+}$requirement was checked in YPG medium with $\mathrm{Na}^{+}$replaced by $\mathrm{K}^{+}$. Growth rates and yields were determined as described previously (Sass et al., 2002). Susceptibility to antibiotics was tested by determination of the MIC in dilute YPG medium using a microtitre approach as outlined by Reeves et al. (1980) and recommended by the American Society for Microbiology (Murray et al., 1995). Antibiotics were diluted in twofold steps from 256 to $0.00195 \mu \mathrm{g} \mathrm{ml}^{-1}$ (chloramphenicol, erythromycin, gentamicin, kanamycin, streptomycin, tetracycline, trimethoprim) or 3200 to $0.0244 \mathrm{U}$ (penicillin G) and cell titres were adjusted to $10^{6}$ cells $\mathrm{ml}^{-1}$ in each well at the start of the experiment. Vitamin requirement was tested in mineral medium with $5 \mathrm{mM}$ glucose and a mixture of the common $20 \mathrm{~L}$-amino acids (each at $10 \mu \mathrm{M}$ ). Eight different assays lacking one of the following vitamins were prepared: $p$-aminobenzoate, biotin, folate, lipoate, nicotinate, pantothenate, pyridoxine and thiamine. Results were confirmed in at least three consecutive subcultures. Tateyamaria omphalii IAM $15108^{\mathrm{T}}$, Roseobacter litoralis DSM $6996^{\mathrm{T}}$ and Sulfitobacter pontiacus DSM $10014^{\mathrm{T}}$ were used as reference organisms. Whole-cell fatty acid patterns were analysed in cells grown aerobically with acetate as the sole electron and carbon source. Cells were harvested at the end of the exponential phase and washed with PBS buffer (130 mmol NaCl $1^{-1}, 10 \mathrm{mmol}$ sodium phosphate buffer $1^{-1}, \mathrm{pH}$ 7.2). Sequencing of the $16 \mathrm{~S}$ rRNA gene and phylogenetic analysis were performed as described by Sass et al. (2002).

For whole cell fatty acid patterns, freeze-dried cells were subjected to alkaline hydrolysis and subsequent acidification and extraction as described by Sass et al. (2002). In contrast to the MIDI procedure (Sasser, 1997), fatty acids were converted to their trimethylsilyl (TMS) ester derivatives using $\mathrm{N}$-methyl-N-trimethylsilyltrifluoroacetamide (CS Chromatographie Service, Langerwehe, Germany). The esterified fatty acids were analysed by GC-FID. Double bond positions of monounsaturated fatty acids were confirmed by preparation of dimethyldisulfide adducts and GC-MS analysis (Rütters et al., 2002; Sass et al., 2002). Extraction and fractionation of lipids and analysis of polar lipids (including phospholipids) were performed as described previously (Rütters et al., 2001, 2002).

Strain SAM4 ${ }^{\mathrm{T}}$ was isolated from an MPN series $\left[6 \times 10^{7}\right.$ cells (g sediment $)^{-1}$ ] using a standard dilution plating technique. Older colonies became pinkish on nutrient-rich $\mathrm{MB}$, but remained beige on YPG agar. Cells were Gramnegative rods $(0.7-1.4 \mu \mathrm{m}$ wide and 1.5-3.0 $\mu \mathrm{m}$ long) and were motile by means of a single flagellum. Endospores were not observed. Strain SAM4 ${ }^{\mathrm{T}}$ exhibited catalase and oxidase activities. Like its closest relative, T. omphalii IAM $15108^{\mathrm{T}}$, strain SAM4 ${ }^{\mathrm{T}}$ did not hydrolyse agar, alginate, or gelatin, whereas weak cellulase and chitinase activities were found. No acid production from carbohydrates was found 
in strain $\mathrm{SAM} 4^{\mathrm{T}}$, whereas $T$. omphalii IAM $15108^{\mathrm{T}}$ produced acid from D-mannose and D-glucose. Further biochemical parameters of strain SAM $4^{\mathrm{T}}$ and T. omphalii IAM $15108^{\mathrm{T}}$ are given in Table 1 and the species descriptions. Bacteriochlorophyll $a$ was detected only in older cultures of strain SAM $4^{\mathrm{T}}$ grown in the dark or under diurnal light/dark cycles. Spectra revealed characteristic peaks at $768-770 \mathrm{~nm}$ and $477-481 \mathrm{~nm}$, and a smaller one at 594-595 nm. A very similar spectrum was obtained with Roseobacter denitrificans DSM $7001^{\mathrm{T}}$ as a reference strain. The DNA G + C content of strain SAM4 ${ }^{\mathrm{T}}$ was $56.4 \mathrm{~mol} \%$.

Strain SAM $4^{\mathrm{T}}$ and T. omphalii IAM $15108^{\mathrm{T}}$ required $\mathrm{Na}^{+}$ and grew at salinities of $0.3-10.2 \%$ and $0.2-6.0 \%$, respectively. The $\mathrm{pH}$ ranges for growth were 6.0-9.0 (strain SAM $^{\mathrm{T}}$ ) and 5.4-8.9 (T. omphalii IAM $\left.15108^{\mathrm{T}}\right)$. Strain $\mathrm{SAM} 4{ }^{\mathrm{T}}$ grew at temperatures between 4 and $35^{\circ} \mathrm{C}$, with optimum growth at $25{ }^{\circ} \mathrm{C}$ [growth rate $(\mu)$ on YPG was $1.72 \mathrm{~d}^{-1}$ ] and showed more or less constant growth yields with values around $140 \mathrm{mg}$ dry weight per 1 YPG medium at temperatures between 4 and $30{ }^{\circ} \mathrm{C}$ (see Supplementary Fig. S1, available in IJSEM Online). However, plotting $\log (\mu)$ against the inverse temperature in an Arrhenius plot revealed that a linear increase was restricted to temperatures between 4 and $20{ }^{\circ} \mathrm{C}$. At temperatures above $20{ }^{\circ} \mathrm{C}$, $\log (\mu)$ hardly increased, indicating harmful temperature effects (data not shown). Due to its temperature range for growth and growth yield to temperature relationship, strain $\mathrm{SAM} 4^{\mathrm{T}}$ can be characterized as psychrotolerant (Isaksen \& Jørgensen, 1996).

Strain SAM4 ${ }^{\mathrm{T}}$ was nutritionally versatile, utilizing a wide range of substrates such as peptone, carbohydrates, amino acids and organic acids such as lactate or acetate, whereas primary alcohols or aromatic compounds were not utilized (see Table 1 and species description). No growth was observed using the $\mathrm{C}_{1}$-compounds formate, methanol, methylamine, dimethyl sulfide or DMSO. T. omphalii IAM $15108^{\mathrm{T}}$ utilized similar substrates including carbohydrates, and amino, dicarboxylic and fatty acids (see Table 1 and species description), but in contrast to strain $\mathrm{SAM} 4^{\mathrm{T}}$ also grew with some aliphatic alcohols. Strain $\mathrm{SAM} 4^{\mathrm{T}}$ oxidized sulfite, thiosulfate and elemental hydrogen, but not elemental sulfur, whereas T. omphalii IAM $15108^{\mathrm{T}}$ oxidized neither hydrogen nor sulfur compounds. Hydrogen consumption was also found in $R$. litoralis DSM $6996^{\mathrm{T}}$, but not in S. pontiacus DSM $10014^{\mathrm{T}}$.

Strain SAM4 $4^{\mathrm{T}}$ grew anaerobically with acetate as electron donor and TMAO as electron acceptor, but not with DMSO, nitrate, nitrite, sulfite, elemental sulfur, thiosulfate, soluble ferric citrate, iron hydroxide, manganese oxides, AQDS or humic acids. T. omphalii IAM $15108^{\mathrm{T}}$ reduced nitrate (Kurahashi \& Yokota, 2007) and TMAO, but none of the other electron acceptors tested. However, growth in assays with TMAO was very weak and cells were generally elongated by up to ten times the normal length indicating unfavourable conditions. TMAO reduction was also found in $R$. denitrificans, but occurred only in the light (Shiba,
1991). S. pontiacus DSM $10014^{\mathrm{T}}$ reduced DMSO, but no anaerobic respiration was found with $R$. litoralis DSM $6996^{\mathrm{T}}$. Strain SAM4 ${ }^{\mathrm{T}}$ grew fermentatively on anoxic sulfide-reduced media. Generally, anaerobic growth on mineral medium with glucose ceased after one to three transfers, but persisted longer on anaerobic MB. As indicated by the colourless redox indicator resazurin, the positive assays were indeed oxygen-free. However, although visible colonies were formed under clearly anoxic conditions, these generally became smaller with each transfer until subculturing under anoxic conditions failed. At the moment, we can only speculate about the reason for this growth behaviour, but it may indicate the failure of an assimilatory pathway under anoxic conditions that can at least partly be compensated for by the use of complex media like MB. Reproducible anaerobic growth on complex MB or R2A (Becton Dickinson) was also found with T. omphalii IAM $15108^{\mathrm{T}}$ and $S$. pontiacus DSM $10014^{\mathrm{T}}$. Although liquid anoxic cultures generally did not become turbid, they were dominated by dividing cells and cell numbers reached up to $10^{7} \mathrm{ml}^{-1}$.

The antibiotic MICs determined for strain $\mathrm{SAM} 4^{\mathrm{T}}, T$. omphalii IAM $15108^{\mathrm{T}}$, $R$. litoralis DSM $6996^{\mathrm{T}}$ and $S$. pontiacus DSM $10014^{\mathrm{T}}$ are given in Table 2. Strain SAM4 ${ }^{\mathrm{T}}$ required biotin, pantothenate and thiamine for growth, whereas T. omphalii IAM $15108^{\mathrm{T}}$ required only pantothenate and biotin. In our tests, $R$. litoralis DSM $6996^{\mathrm{T}}$ and $S$. pontiacus DSM $10014^{\mathrm{T}}$ required biotin, nicotinate and thiamine, thus confirming previous reports (Shiba, 1991; Sorokin, 1995).

The major phospholipids of strain SAM4 ${ }^{\mathrm{T}}$ were phosphatidylglycerol (PG; 72\%) and phosphatidylethanolamine (PE; $28 \%$ ). Phosphatidylcholine (PC) and an unidentified lipid were present in trace amounts. The dominant fatty acid was $n-\mathrm{C}_{18: 1} \omega 7 c(90.6 \%)$. Other fatty acids present in lower amounts included $n$ - $\mathrm{C}_{16: 0}(4.9 \%), \quad n-\mathrm{C}_{16: 1} \omega 7 c$ $(1.2 \%), \quad n-\mathrm{C}_{18: 0} \quad(0.9 \%), \quad n-\mathrm{C}_{14: 0} \quad(0.8 \%), \quad 11$-methyl$\mathrm{C}_{18: 1}(0.7 \%)$ and $n-\mathrm{C}_{18: 1} \omega 9 c(0.4 \%)$, whereas only traces $(<0.2 \%)$ of $n-\mathrm{C}_{14: 1} \omega 5 c$, ai- $\mathrm{C}_{15: 0}, \mathrm{i}-\mathrm{C}_{16: 0}$ and $n-\mathrm{C}_{16: 1} \omega 9 c$ were detected.

Phylogenetic analysis based on 16S rRNA gene sequences revealed that strain SAM4 ${ }^{\mathrm{T}}$ was most closely related to $T$. omphalii IAM $15108^{\mathrm{T}}$ (97.1\% similarity). High similarities were also found to $R$. litoralis DSM $6996^{\mathrm{T}}(96.5 \%), R$. denitrificans DSM $7001^{\mathrm{T}}(96.2 \%)$ and Sulfitobacter mediterraneus DSM $12244^{\mathrm{T}}$ (96.1\%). The maximum-likelihood tree shown in Fig. 1 is typical of all trees obtained showing the position of strain SAM4 $4^{\mathrm{T}}$ and Tateyamaria omphalii IAM $15108^{\mathrm{T}}$ on a separate branch close to members of the genera Roseobacter and Sulfitobacter.

The phylogenetic grouping of strain $\mathrm{SAM} 4^{\mathrm{T}}$ and $T$. omphalii IAM $15108^{\mathrm{T}}$ into a single genus is supported by the results of phenotypic investigations. Both strains exhibit almost identical enzyme patterns (except for ornithine deaminase) and utilize similar substrates. They can be distinguished from species of the genera Roseobacter 
Table 1. Differential phenotypic characteristics of strain SAM4 ${ }^{\top}$ and members of the genera Tateyamaria, Roseobacter, Sulfitobacter and Oceanibulbus

Taxa: 1, strain SAM4 ${ }^{\mathrm{T}}$ (data from this study); 2, T. omphalii IAM 15108 ${ }^{\mathrm{T}}$ (Kurahashi \& Yokota, 2007); 3, R. litoralis DSM 6996 ${ }^{\mathrm{T}}$ (Shiba, 1991); 4, R. denitrificans DSM 7001 ${ }^{\mathrm{T}}$ (Shiba, 1991); 5, S. pontiacus DSM $10014^{\mathrm{T}}$ (Sorokin, 1995), 6, S. mediterraneus DSM $12244^{\mathrm{T}}$ (Pukall $^{\text {(S) }}$ et al., 1999); 7, S. donghicola JCM 14565 ${ }^{\mathrm{T}}$ (Yoon et al., 2007); 8, S. guttiformis DSM 11458 ${ }^{\mathrm{T}}$ (Labrenz et al., 2000); 9, S. brevis DSM 11443 ${ }^{\mathrm{T}}$ (Labrenz et al., 2000); 10, O. indolifex DSM $14862^{\mathrm{T}}$ (Wagner-Döbler et al., 2004). +, Positive; -, negative; (+), weakly positive; tr, trace; $\mathrm{ND}$, not determined or not described. All of the taxa shown are positive for catalase and oxidase, and require $\mathrm{Na}^{+}$for growth.

\begin{tabular}{|c|c|c|c|c|c|c|c|c|c|c|}
\hline Characteristic & 1 & 2 & 3 & 4 & 5 & 6 & 7 & 8 & 9 & 10 \\
\hline Rosettes & - & - & - & - & + & + & ND & + & + & $\mathrm{ND}$ \\
\hline Bacteriochlorophyll $a$ & + & - & + & + & $-{ }^{\star}$ & - & - & + & - & - \\
\hline DNA G $+C$ content $(\mathrm{mol} \%)$ & 56.4 & 61.6 & 59.6 & $56.3-58$ & 62.1 & 59 & 56.9 & $55-56$ & 58 & 60.1 \\
\hline $37^{\circ} \mathrm{C}$ & - & + & - & - & - & - & - & - & - & - \\
\hline $\mathrm{pH}$ range & $6-9$ & $5.4-8.9 \dagger$ & $7.0-9.5$ & $7.0-9.5$ & $6.5-8.5$ & $6.5-8.5$ & $6-9$ & $5.5-9.5$ & $5.5-9.5$ & $7-9$ \\
\hline \multicolumn{11}{|l|}{ Hydrolysis of: } \\
\hline Gelatin & - & - & + & + & $-\ddagger$ & + & - & - & - & - \\
\hline Starch & - & $+\dagger$ & - & - & $+^{*}$ & $+^{*}$ & - & - & - & - \\
\hline Trehalose & + & $+\dagger$ & $+\ddagger$ & $+\ddagger$ & $-\dagger$ & $\mathrm{ND}$ & - & $(+)$ & + & - \\
\hline D-Mannose & + & $+\dagger$ & $+\ddagger$ & $+\ddagger$ & $-\dagger$ & - & - & $(+)$ & + & - \\
\hline L-Arabinose & - & $-\dagger$ & $+1-\ddagger$ & $+\ddagger$ & $-\dagger$ & - & - & - & + & - \\
\hline D-Gluconate & + & $+\dagger$ & $+\ddagger$ & $+\ddagger$ & + & + & ND & - & $(+)$ & - \\
\hline DL-Lactate & + & $+\dagger$ & $-\ddagger$ & + & + & + & ND & - & - & + \\
\hline Acetate & + & $+\dagger$ & + & + & + & + & - & + & + & - \\
\hline Butyrate & - & $+\dagger$ & - & - & + & + & - & - & + & - \\
\hline L-Ornithine & + & $+\dagger$ & $-末$ & $-\ddagger$ & + & + & ND & - & - & + \\
\hline Nitrate reduction & - & + & - & + & $+\S$ & - & - & - & - & - \\
\hline Oxidation of sulfite & + & $-\dagger$ & $-\dagger$ & ND & + & + & ND & - & - & ND \\
\hline \multicolumn{11}{|l|}{ Vitamin requirement: } \\
\hline Tetracycline (30) & + & $-\dagger$ & $-\dagger$ & + & $+^{*}$ & $+^{*}$ & + & + & + & $\mathrm{ND}$ \\
\hline \multicolumn{11}{|l|}{ Presence of: } \\
\hline$n-\mathrm{C}_{18: 2}$ & - & - & $+\ddagger$ & $-\ddagger$ & $-\|$ & - & - & + & + & + \\
\hline$n-\mathrm{C}_{18: 0}$ & + & - & $+\ddagger$ & $+\ddagger$ & +11 & + & + & + & + & - \\
\hline 11-methyl- $\mathrm{C}_{18: 1}$ & + & + & $-\ddagger$ & $-\ddagger$ & -11 & + & + & - & + & - \\
\hline cyclo- $\mathrm{C}_{19}$ FA & - & + & $-\ddagger$ & $-\ddagger$ & -11 & - & - & - & - & - \\
\hline PG & + & ND & +9 & +9 & $+\#$ & ND & + & + & + & + \\
\hline $\mathrm{PE}$ & + & ND & $-\mathbf{g}$ & -9 & $+\#$ & ND & + & + & + & + \\
\hline PC & $\operatorname{tr}$ & ND & +9 & -9 & $-\#$ & ND & + & + & + & + \\
\hline DPG & - & ND & +9 & +9 & $+\#$ & ND & $(+)$ & - & + & + \\
\hline Unidentified aminolipid & - & ND & +9 & +9 & $-\#$ & ND & - & + & + & + \\
\hline
\end{tabular}




\section{Table 1. cont.}

${ }^{\star}$ Data from Yoon et al. (2007).

$\dagger$ Data from this study.

$\ddagger$ Data from Labrenz et al. (1999).

$\S$ Data from Ivanova et al. (2004).

IIData from Pukall et al. (1999).

SData from Labrenz et al. (1998).

\#Data from Labrenz et al. (2000).

and Sulfitobacter by their vitamin requirement (requirement for pantothenate, but not for nicotinate) and their physiological capacities (absence of casein and Tween 80 hydrolysis) and their insensitivity to kanamycin. In contrast to species of the genus Roseobacter, strain SAM4 $4^{\mathrm{T}}$ and T. omphalii IAM $15108^{\mathrm{T}}$ utilize L-ornithine and cellobiose, but not L-arabinose, whereas species of the genus Sulfitobacter generally do not utilize the disaccharides cellobiose, maltose and trehalose or D-mannose. Like T. omphalii IAM $15108^{\mathrm{T}}$, strain $\mathrm{SAM} 4^{\mathrm{T}}$ contains the branched 11-methyl- $\mathrm{C}_{18: 1}$ fatty acid, which is also found in some species of the genus Sulfitobacter, but is absent in species of the genus Roseobacter and in Oceanibulbus indolifex DSM $14862^{\mathrm{T}}$ (Table 1); and both lack the $n$-C $\mathrm{C}_{18: 2}$ fatty acid which is widespread among species of the genera Roseobacter, Sulfitobacter and Oceanibulbus. However, it may be that some of these differences are due to variations in the analytical procedures applied. Strain SAM4 $4^{\mathrm{T}}$ differs from members of the genus Roseobacter with respect to its phospholipids as it contains almost exclusively PE and PG, whereas in species of the genus Roseobacter PE is absent, but diphosphatidylglycerol (DPG) is a major lipid (Labrenz et al., 1998). DPG is also present in O. indolifex DSM $14862^{\mathrm{T}}$ (Wagner-Döbler et al., 2004) and in most species of the genus Sulfitobacter (e.g. Labrenz et al., 2000; Ivanova et al., 2004). The only reported exception is Sulfitobacter guttiformis DSM $11458^{\mathrm{T}}$ (formerly Staleya guttiformis),

Table 2. MICs determined for strain $S A M 4^{\top}$ and the type strains of $T$. omphalii, $R$. litoralis and $S$. pontiacus

Strains: 1 , SAM $4^{\mathrm{T}} ; 2$, T. omphalii IAM $15108^{\mathrm{T}} ; 3$, R. litoralis DSM $6996^{\mathrm{T}} ; 4$, S. pontiacus DSM $10014^{\mathrm{T}}$. Concentrations are given in $\mu \mathrm{g} \mathrm{ml}^{-1}$, except for penicillin $\mathrm{G}(\mathrm{U})$.

\begin{tabular}{|lcccc|}
\hline Antibiotic & $\mathbf{1}$ & $\mathbf{2}$ & $\mathbf{3}$ & $\mathbf{4}$ \\
\hline Chloramphenicol & 0.25 & 4 & 0.5 & 0.5 \\
Erythromycin & 0.25 & 0.063 & 8 & 16 \\
Gentamicin & 2 & 512 & 8 & 16 \\
Kanamycin & 256 & $>512$ & 32 & 64 \\
Penicillin G & $<0.002$ & 0.016 & $<0.002$ & 0.5 \\
Streptomycin & 4 & 128 & 64 & 128 \\
Tetracycline & 4 & 512 & 128 & 64 \\
Trimethoprim & 256 & 2 & 256 & $>256$ \\
\end{tabular}

which, like strain SAM4 ${ }^{\mathrm{T}}$, contains $\mathrm{PG}, \mathrm{PE}$ and PC and produces bacteriochlorophyll $a$ (Labrenz et al., 2000).

In conclusion, phylogenetic evidence based on 16S rRNA gene sequences, physiological and lipid data suggest that strain SAM $4^{\mathrm{T}}$ represents a novel species within the genus Tateyamaria, for which the name Tateyamaria pelophila is proposed.

\section{Emended description of the genus Tateyamaria Kurahashi and Yokota 2007}

The description is based on that given by Kurahashi \& Yokota (2007) with the following amendments and changes. Cells may be motile by polar flagella and may produce bacteriochlorophyll $a$. Cells are positive for catalase, oxidase and phosphatase. The type species is Tateyamaria omphalii.

\section{Description of Tateyamaria pelophila sp. nov.}

Tateyamaria pelophila (pe.lo' phi.la. Gr. n. pelos mud; Gr. adj. philos - $\hat{e}$-on loving; N.L. fem. adj. pelophila mudloving).

Gram-negative rods, $0.7-1.4 \mu \mathrm{m}$ wide and $1.5-3.0 \mu \mathrm{m}$ long. Motile by means of a polar flagellum. Colonies on $\mathrm{MB}$ agar plates are beige to pinkish. Temperature range for growth is $4-35{ }^{\circ} \mathrm{C}$, with fastest growth at $25{ }^{\circ} \mathrm{C}$. Growth is observed between pH 6 and 9 and at salinities from 0.3 to $10.2 \%$. Requires $\mathrm{Na}^{+}$. Substrates used aerobically are: peptone, Casamino acids, yeast extract, starch, chitin, xylan, laminarin, cellobiose, maltose, sucrose, trehalose, Dfructose, D-glucose, D-mannose, D-xylose, D-mannitol, Dsorbitol, D-gluconate, D-glucosamine, L-rhamnose, acetate, propionate, valerate, capronate, caprylate, glycolate, DLlactate, pyruvate, succinate, DL-malate, citrate, glycerol, Lalanine, L-arginine, L-asparagine, L-aspartate, L-glutamine, L-glutamate, L-leucine, L-lysine, L-methionine, L-ornithine and L-valine. No growth is observed with chitin, cellulose, L-arabinose, D-ribose, formate, butyrate, crotonate, malonate, DL-tartrate, 2-ketoglutarate, L-cysteine, L-glycine, Lhistidine, L-isoleucine, L-leucine, L-phenylalanine, L-serine, L-threonine, L-tryptophan, L-tyrosine, methanol, ethanol, $n$-propanol, $n$-butanol, betaine, methylamine, ethanolamine, DMSO, dimethylsulfide, benzoate, salicylate or nicotinate. Grows anaerobically for a few transfers with glucose as substrate or on MB. Under anoxic conditions, 


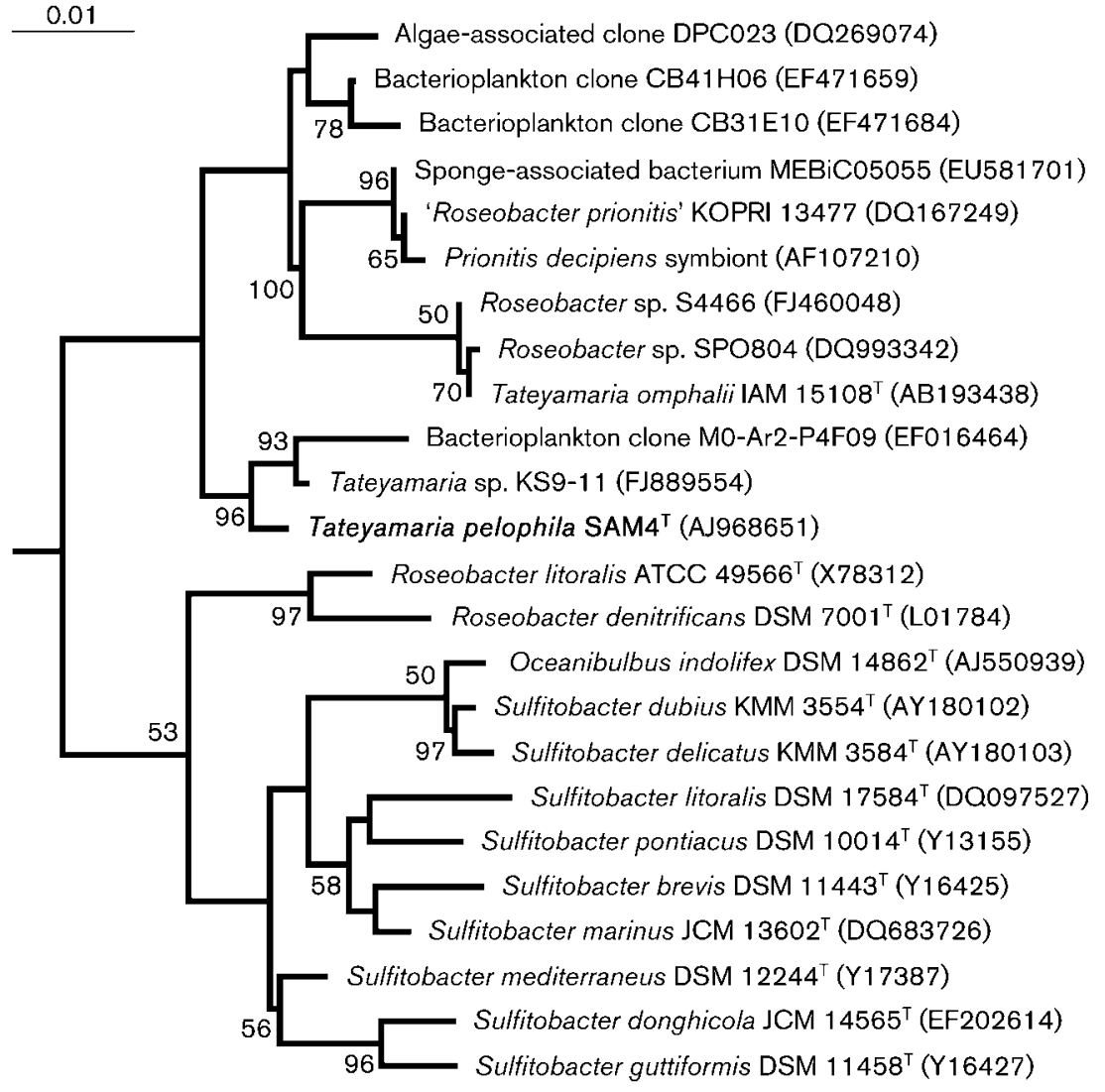

Fig. 1. Maximum-likelihood tree based on 16S rRNA sequences showing the phylogenetic position of strain SAM4 ${ }^{\top}$ within the Roseobacter clade of the class Alphaproteobacteria. Jannaschia helgolandensis Hel $10^{\top}$ (GenBank accession no. AJ438157) served as outgroup (not shown). Bootstrap values of $50 \%$ or more are shown at nodes. Accession numbers are given in parentheses. Bar, $1 \%$ sequence divergence.
TMAO serves as an electron acceptor, whereas DMSO, nitrate, nitrite, sulfite, elemental sulfur, thiosulfate, ferric citrate, iron hydroxide, manganese oxides, AQDS and humic acids are not reduced. Sulfite, thiosulfate and elemental hydrogen are oxidized lithoheterotrophically, but not elemental sulfur or carbon monoxide. Weak manganese-oxidizing activity. Cells exhibit oxidase and catalase activity and contain bacteriochlorophyll $a$. Sulfide is not produced from L-cysteine, L-methionine or thiosulfate. Agar, agarose, alginate, casein, gelatin, starch, Tweens 20 and 80, tyrosine and xylan are not hydrolysed. Positive for arginine deaminase, tryptophan deaminase, leucine arylaminidase, valine arylaminidase and phosphatase activities. Weak $\beta$-glucosidase and $N$-acetylglucosaminidase activity is present. Negative for arginine dihydrolase, lysine decarboxylase, ornithine decarboxylase, lipase, urease, cysteine arylaminidase and ornithine deaminase. Indole is not produced. Phenylacetate is utilized. Does not produce acid from L-arabinose, D-xylose, D-ribose, D-fructose, D-glucose, D-mannose, D-galactose, cellobiose, maltose, trehalose, sucrose, lactose, L-rhamnose, D-mannitol, D-sorbitol or glycerol. Requires biotin, pantothenate and thiamine for growth, but not $p$-aminobenzoate, folate, lipoate, nicotinate, pyridoxine, cyanocobalamin or riboflavin. Cells are susceptible to chloramphenicol, erythromycin, gentamicin, penicillin G, streptomycin and tetracycline, but are resistant to kanamycin and trimethoprim. The major phospholipids are PE and PG. PC and an unidentified lipid were detected only in trace amounts. The major cellular fatty acid is $n-\mathrm{C}_{18: 1} \omega 7 c$. The following fatty acids are present at lower concentrations: $n-\mathrm{C}_{16: 0}$, n$\mathrm{C}_{14: 1} \omega 5 c, \quad n-\mathrm{C}_{14: 0}, \quad$ ai- $\mathrm{C}_{15: 0}, \quad \mathrm{i}-\mathrm{C}_{16: 0}, \quad n-\mathrm{C}_{16: 1} \omega 7 c, n-$ $\mathrm{C}_{16: 1} \omega 9 c, n-\mathrm{C}_{18: 1} \omega 9 c, n-\mathrm{C}_{18: 0}$ and 11-methyl- $\mathrm{C}_{18: 1}$.

The type strain is SAM $4^{\mathrm{T}}\left(=\mathrm{DSM} 17270^{\mathrm{T}}=\mathrm{LMG} 23018^{\mathrm{T}}\right)$, isolated from tidal-flat sediment on the German North Sea coast. The DNA G $+\mathrm{C}$ content is $56.4 \mathrm{~mol} \%$.

\section{Emended description of Tateyamaria omphalii Kurahashi and Yokota 2007}

Tateyamaria omphalii (om.phal'i.i. N.L. gen. n. omphalii of Omphalius, the genus of the top shell, from which the strain was isolated).

The description of Tateyamaria omphalii is as given by Kurahashi \& Yokota (2007) with the following additions. Growth is observed between $\mathrm{pH} 5.4$ and 8.9 and at salinities from 0.2 to $6.0 \%$. Substrates used aerobically are: peptone, Casamino acids, yeast extract, starch, cellobiose, maltose, sucrose, trehalose, D-fructose, Dmannose, D-xylose, D-mannitol, D-gluconate, D-glucosamine, acetate, propionate, butyrate, valerate, DL-lactate, malonate, succinate, fumarate, DL-malate, 2-ketoglutarate, ethanol, n-propanol, ethylene glycol, glycerol, L-asparagine, L-aspartate, L-glutamine, L-histidine, L-glutamate, L-lysine, L-ornithine, L-proline, L-serine, L-threonine, L-tryptophan, 
L-valine and benzoate. Grows anaerobically for a few transfers on complex media such as R2A or MB. Under anoxic conditions, nitrate and TMAO can serve as electron acceptors, whereas DMSO, nitrite, sulfite, elemental sulfur, thiosulfate, ferric citrate, iron hydroxide, manganese oxides, AQDS or humic acids are not reduced. No growth is observed with chitin, laminarin, cellulose, lactose, Larabinose, D-galactose, D-ribose, D-sorbitol, DL-tartrate, formate, caproate, caprylate, crotonate, glycolate, DLalanine, L-arginine, L-cysteine, L-glycine, L-isoleucine, L-leucine, L-methionine, L-phenylalanine, L-tyrosine, methanol, $n$-butanol, betaine, methylamine, ethanolamine, DMSO, dimethylsulfide, salicylate or nicotinate. Elemental hydrogen, thiosulfate, sulfite, elemental sulfur and $\mathrm{Mn}^{2+}$ are not oxidized. Agar, agarose, alginate, casein, Tween 20, Tween 80, tyrosine and xylan are not hydrolysed. Arginine deaminase, tryptophan deaminase, leucine arylaminidase, valine arylaminidase, ornithine deaminase and phosphatase are present. Negative for $\beta$ glucosidase, $\mathrm{N}$-acetylglucosaminidase, arginine dihydrolase, lysine decarboxylase, ornithine decarboxylase, lipase and cysteine arylaminidase. Phenylacetate is not utilized. Produces acid from D-mannose, but not from D-fructose, cellobiose, D-xylose or trehalose. Requires biotin and pantothenate for growth, but not $p$-aminobenzoate, folate, lipoate, nicotinate, pyridoxine, thiamine, cyanocobalamin or riboflavin. Cells are susceptible to chloramphenicol, erythromycin, penicillin $G$ and trimethoprim, but are resistant to gentamicin, kanamycin, streptomycin and tetracycline.

The type strain is $\mathrm{MKT}_{107^{\mathrm{T}}} \quad\left(=\mathrm{IAM} \quad 15108^{\mathrm{T}}=\mathrm{KCTC}\right.$ $\left.12333^{\mathrm{T}}\right)$, which was isolated from the gastrointestinal tract of the molluscan top shell Omphalius pfeifferi pfeifferi at Chiba, Japan.

\section{Acknowledgements}

Torben Martens and Thorsten Brinkhoff are acknowledged for providing $R$. denitrificans, $R$. litoralis and $S$. pontiacus, and for help with phylogenetic analysis, Erwan Roussel and Andrew Watkins for help with chemical analyses. This work was supported by a grant of the Deutsche Forschungsgemeinschaft (Research Group on BioGeoChemistry of Tidal Flats, FOR 432).

\section{References}

Buchan, A., Gonzalez, J. M. \& Moran, M. A. (2005). Overview of the marine Roseobacter lineage. Appl Environ Microbiol 71, 56655677.

Cohen-Bazire, G., Sistrom, W. R. \& Stanier, R. Y. (1957). Kinetic studies of pigment synthesis by nonsulfur purple bacteria. J Cell Comp Physiol 49, 25-68.

Gerhardt, P., Murray, R. G. E., Wood, W. A. \& Krieg, N. R. (editors) (1994). Methods for General and Molecular Bacteriology. Washington, DC: American Society for Microbiology.

Gonzalez, J. M. \& Moran, M. A. (1997). Numerical dominance of a group of marine bacteria in the $\alpha$-subclass of the class Proteobacteria in coastal seawater. Appl Environ Microbiol 63, 4237-4242.
Gonzalez, J. M., Kiene, R. P. \& Moran, M. A. (1999). Transformation of sulfur compounds by an abundant lineage of marine bacteria in the alpha-subclass of the class Proteobacteria. Appl Environ Microbiol 65, 3810-3819.

Hugenholtz, P., Goebel, B. M. \& Pace, N. R. (1998). Impact of culture-independent studies on the emerging phylogenetic view of bacterial diversity. J Bacteriol 180, 4765-4774.

Isaksen, M. F. \& Jørgensen, B. B. (1996). Adaptation of psychrophilic and psychrotrophic sulfate-reducing bacteria to permanently cold marine environments. Appl Environ Microbiol 62, 408-414.

Ivanova, E. P., Gorshkova, N. M., Sawabe, T., Zhukova, N. V., Hayashi, K., Kurilenko, V. V., Alexeeva, Y., Buljan, V., Nicolau, D. V. \& other authors (2004). Sulfitobacter delicatus sp. nov. and Sulfitobacter dubius sp. nov., respectively from a starfish (Stellaster equestris) and sea grass (Zostera marina). Int J Syst Evol Microbiol 54, 475-480.

Johnson, J. E. \& Hill, R. T. (2003). Sediment microbes of deep-sea bioherms on the Northwest Shelf of Australia. Microb Ecol 46, 55-61.

Köpke, B., Wilms, R., Engelen, B., Cypionka, H. \& Sass, H. (2005). Microbial diversity in coastal subsurface sediments: a cultivation approach using various electron acceptors and substrate gradients. Appl Environ Microbiol 71, 7819-7830.

Kurahashi, M. \& Yokota, A. (2007). Tateyamaria omphalii gen. nov., sp. nov., an $\alpha$-Proteobacterium isolated from a top shell Omphalius pfeifferi pfeifferi. Syst Appl Microbiol 30, 371-375.

Labrenz, M., Collins, M. D., Lawson, P. A., Tindall, B. J., Braker, G. \& Hirsch, P. (1998). Antarctobacter heliothermus gen. nov., sp. nov., a budding bacterium from hypersaline and heliothermal Ekho Lake. Int J Syst Bacteriol 48, 1363-1372.

Labrenz, M., Collins, M. D., Lawson, P. A., Tindall, B. J., Schumann, P. \& Hirsch, P. (1999). Roseovarius tolerans gen. nov., sp. nov., a budding bacterium with variable bacteriochlorophyll $a$ production from hypersaline Ekho Lake. Int J Syst Bacteriol 49, 137-147.

Labrenz, M., Tindall, B. J., Lawson, P. A., Collins, M. D., Schumann, P. \& Hirsch, P. (2000). Staleya guttiformis gen. nov., sp. nov. and Sulfitobacter brevis sp. nov., $\alpha$-3-Proteobacteria from hypersaline, heliothermal and meromictic antarctic Ekho Lake. Int J Syst Evol Microbiol 50, 303-313.

Martens-Habbena, W. \& Sass, H. (2006). Sensitive determination of microbial growth by nucleic acid staining in aqueous suspension. Appl Environ Microbiol 72, 87-95.

Mesbah, M., Premachandran, U. \& Whitman, W. B. (1989). Precise measurement of the $\mathrm{G}+\mathrm{C}$ content of deoxyribonucleic acid by highperformance liquid chromatography. Int J Syst Bacteriol 39, 159-167.

Mullins, T. D., Britschgi, T. B., Krest, R. L. \& Giovannoni, S. J. (1995). Genetic comparisons reveal the same unknown bacterial lineages in Atlantic and Pacific bacterioplankton communities. Limnol Oceanogr 40, 148-158.

Murray, P. R., Baron, E. J., Pfaller, M. A., Tenover, F. C. \& Yolken, R. H. (1995). Manual of Clinical Microbiology, 6th edn. Washington, DC: American Society for Microbiology.

Pukall, R., Buntefuß, D., Frühling, A., Rohde, M., Kroppenstedt, R. M., Burghardt, J., Lebaron, P., Bernard, L. \& Stackebrandt, E. (1999). Sulfitobacter mediterraneus sp. nov., a new sulfite-oxidizing member of the $\alpha$-Proteobacteria. Int J Syst Bacteriol 49, 513-519.

Rappé, M. S. \& Giovannoni, S. J. (2003). The uncultured microbial majority. Annu Rev Microbiol 57, 369-394.

Reeves, D. S., Holt, A., Bywater, M. J., Wise, R., Logan, M. N., Andrews, J. M. \& Broughall, J. M. (1980). Comparison of sensititre dried microtitration trays with a standard agar method for determination of minimum inhibitory concentrations of antimicrobial agents. Antimicrob Agents Chemother 18, 844-852. 
Rütters, H., Sass, H., Cypionka, H. \& Rullkötter, J. (2001). Monoalkylether phospholipids in the sulfate-reducing bacteria Desulfosarcina variabilis and Desulforhabdus amnigenus. Arch Microbiol 176, 435-442.

Rütters, H., Sass, H., Cypionka, H. \& Rullkötter, J. (2002). Phospholipid analysis as a tool to study microbial communities J Microbiol Methods 48, 149-160.

Sass, A., Rütters, H., Cypionka, H. \& Sass, H. (2002). Desulfobulbus mediterraneus sp. nov., a sulfate-reducing bacterium growing on mono- and disaccharides. Arch Microbiol 177, 468-474.

Sasser, M. (1990). Identification of bacteria by gas chromatography of cellular fatty acids, MIDI Technical Note 101. Newark, DE: MIDI Inc.

Selje, N., Simon, M. \& Brinkhoff, T. (2004). A newly discovered Roseobacter cluster in temperate and polar oceans. Nature 427, 445-448.

Shiba, T. (1991). Roseobacter litoralis gen. nov., sp. nov., and Roseobacter denitrificans sp. nov., aerobic pink-pigmented bacteria which contain bacteriochlorophyll a. Syst Appl Microbiol 14, 140-145.

Sorokin, D. Y. (1995). Sulfitobacter pontiacus gen. nov., sp. nov. - a new heterotrophic bacterium from the Black Sea, specialized on sulfite oxidation. Microbiology (English translation of Mikrobiologiia) 64, 295-305.
Süß, J., Engelen, B., Cypionka, H. \& Sass, H. (2004). Quantitative analysis of bacterial communities from Mediterranean sapropels based on cultivation-dependent methods. FEMS Microbiol Ecol 51, 109-121.

Süß, J., Herrmann, K., Seidel, M., Cypionka, H., Engelen, B. \& Sass, H. (2008). Two distinct Photobacterium populations thrive in ancient Mediterranean sapropels. Microb Ecol 55, 371-383.

Wagner-Döbler, I., Rheims, H., Felske, A., El-Ghezal, A., FladeSchröder, D., Laatsch, H., Lang, S., Pukall, R. \& Tindall, B. J. (2004). Oceanibulbus indolifex gen. nov., sp. nov., a North Sea alphaproteobacterium that produces bioactive metabolites. Int J Syst Evol Microbiol 54, 1177-1184.

Webster, G., Blazejak, A., Cragg, B. A., Schippers, A., Sass, H., Rinna, J., Tang, X., Mathes, F., Ferdelman, T. \& other authors (2009). Subsurface microbiology and biogeochemistry of a deep, cold-water carbonate mound from the Porcupine Seabight (IODP Expedition 307). Environ Microbiol 11, 239-257.

Yoon, J.-H., Kang, S.-J., Lee, M.-H. \& Oh, T.-K. (2007). Description of Sulfitobacter donghicola sp. nov., isolated from seawater of the East Sea in Korea, transfer of Staleya guttiformis Labrenz et al. 2000 to the genus Sulfitobacter as Sulfitobacter guttiformis comb. nov. and emended description of the genus Sulfitobacter. Int J Syst Evol Microbiol 57, 1788-1792. 